\title{
SEASONAL VARIATION IN SOIL STRUCTURE
}

\author{
Reijo Heinonen and Risto Pukkala \\ Agricultural Research Centre, Department of Soil Science, Helsinki \\ Received 15th April 1954.
}

The seasonal variation in soil structure is important, especially from the point of view of methodology in physical soil investigations. For, since the aim of these studies is usually to describe the permanent or slowly changing properties oi the soil, the effect of seasonal factors on the research material should be eliminated.

\section{Experimental}

Three sample plots, each 10 by 10 meters, were chosen from the Viik experimental farm near Helsinki. The soil is clay loam (average texture: 40 per cent clay, 20 per cent silt $2-20 \mu$, the rest mainly very fine sand) with about 5 per cent organic matter. The $\mathrm{pH}$ of different plots was as follows: 1. $\mathrm{pH} 6.9,2 . \mathrm{pH} 6.4$, 3. $\mathrm{pH}$ 5.6. The crop made the main difference between the plots: 1. spring wheat

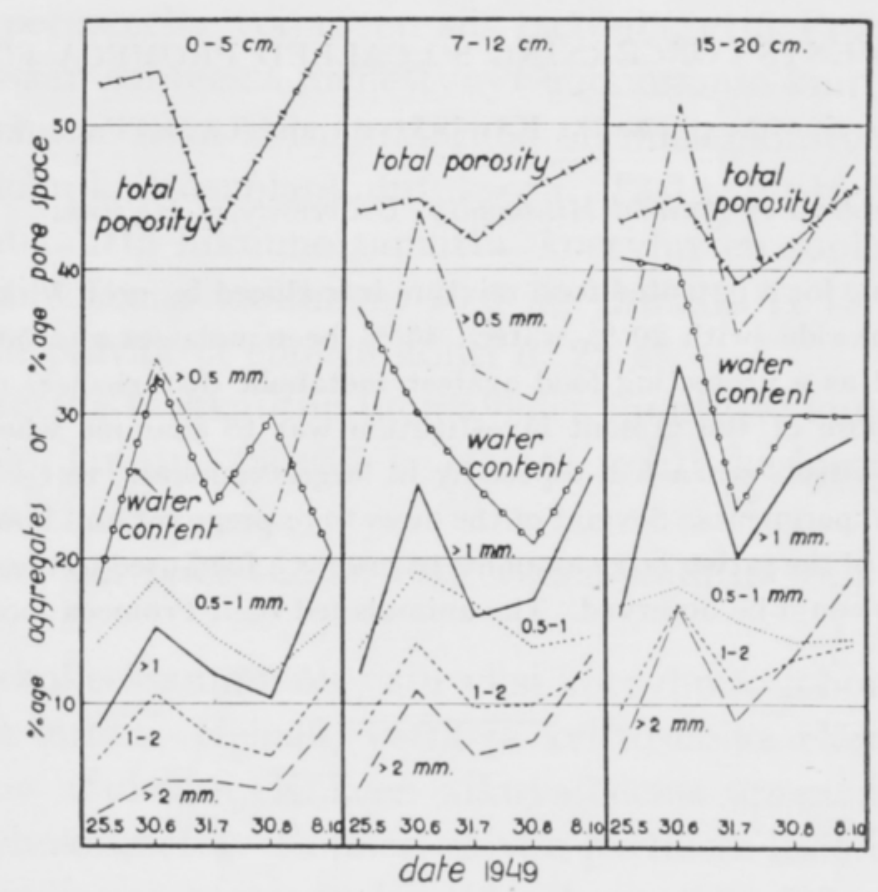

Fig. 1. Seasonal varation in aggregation, total porosity and moisture content of a clay loam topsoil under spring wheat (plot 1). 


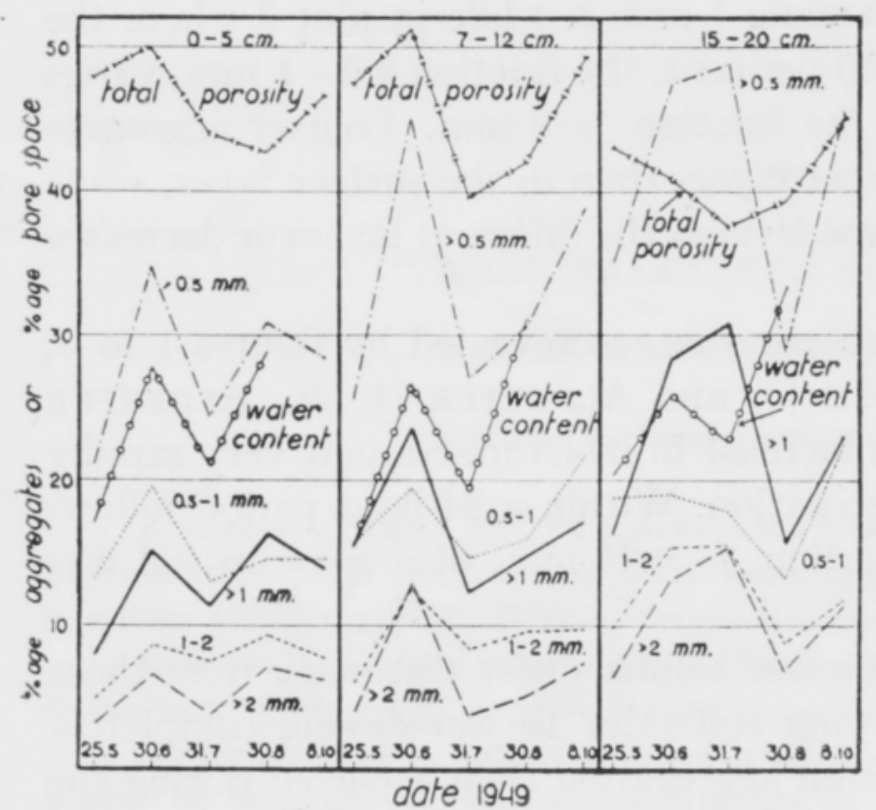

Fig. 2. Seasonal variation in aggregation, total porosity and moisture content of a clay loam topsoil under 2nd year clover-timothy ley (plot 2).

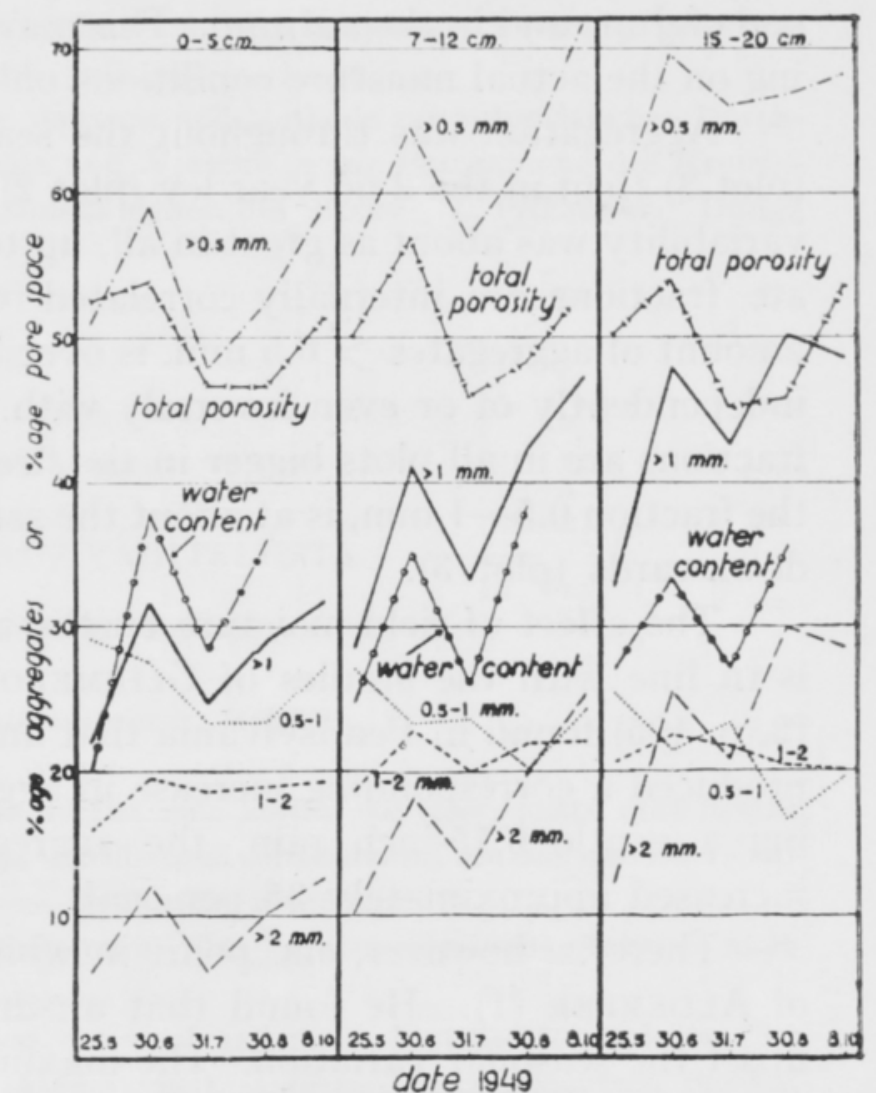

Fig. 3. Seasonal variation in aggregation, total porosity and moisture content of a clay loam topsoil under 5th year pasture grass (plot 3 ).

with ley seeds undersown, 2. second year clover-timothy ley, 3. fifth year pasture grass.

The layers $0-5 \mathrm{~cm} ., 7-12 \mathrm{~cm}$., and $15-20 \mathrm{~cm}$. of each plot were sampled five times during the summer of 1949 at about monthly intervals. The sampling was done with a 50 by $70 \mathrm{~mm}$. cylinder in 8 replicates. The samples were weighed immediately in the field and later in the air-dry condition. In connection with the latter weighing, the specific gravity of the soil was determined by a rapid method (4, p. 77). Wet-sieving analyses were made from the air-dry samples with the automatic apparatus of Meyer and v. RennenkampfF (5), after 20 minutes' preliminary soaking. Because of the large number of replicates, the standard error of the porosity and aggregation analysis presented in figs. 1 to 3 was rather low, generally below 1 per cent.

\section{Discussion}

The total porosity of the topsoil changed up to 10 per cent in a month. Somewhat parallel changes took place in different plots and horizons. Especially in the $7-12 \mathrm{~cm}$. layer of the grass plots, the total porosity was closely correlated with the amount of water-stable aggregates and with the moisture content. The total porosity was generally at a minimum in July-August and at a maximum in the 
end of June and in the autumn. This may, however, be an accidental trend, depending on the actual moisture conditions only.

Aggregation was throughout the season definitely better in the 5 th year ley (plot 3) than in the 2 nd year ley (plot 2) or spring wheat (plot 1), but the seasonal variability was about as great in all, up to 20 per cent in a month. Different aggregate fractions are internally correlated in plots 1 and 2 , while in plot 3 where the amount of aggregates $>0.5 \mathrm{~mm}$. is over 50 per cent, the fraction $0.5-1 \mathrm{~mm}$. varies independently of or even inversely with the fraction $>2 \mathrm{~mm}$. Coarser aggregate fractions are in all plots bigger in the deeper layers than in the surface layer, while the fraction $0.5-1 \mathrm{~mm}$. is at about the same level in the different layers or decreases downwards (plot 3).

The effect of field-moisture on the aggregation, as revealed by figures 1 to 3 , is in line with the studies of Gliemeroth (3) and Alderfer (1, 2). Alderfer (2, p. 195) found in Pennsylvania that an increase in moisture content very rapidly produced a corresponding increase in aggregation. Within a 24 -hour period following a gentle 0.75 -inch rain, the aggregation $>0.25 \mathrm{~mm}$. of a siltloam soil was increased approximately 35 per cent.

There is, however, one point in which our results differ distinctly from those of ALDERFER (1). He found that air-drying soil prior to wet-sieving completely upset the seasonal variation. The maximum aggregation then occurred during the dry midsummer, and the variation as a whole was much slighter than if assessed in the field-moist condition. We, on the contrary, found wide seasonal variation although wet-sieving was only done after air-drying. The effect of air-drying on aggregation apparently varies under different conditions.

$$
\text { Conclusions }
$$

The seasonal variation in porosity and aggregation is so wide that samplings made at different times are hardly comparable.

The aggregation, as assessed by wet-sieving after air-drying, and porosity are often directly correlated with soil moisture. Therefore it might be advisable to bring differently treated soils to a uniform moisture condition (field capacity) before sampling, if more permanent structural properties are to be compared, and seasonal effects to be eliminated.

\section{References}

(1) Alderfer, R. B. 1946. Seasonal variability in the aggregation of Hagerstown silt loam. Soil Sci., 62 , p. $151-168$.

(2) - - 1950. Influence of seasonal and cultural conditions on aggregation of Hagerstown soil. Ibid., 69 , p. $193-203$.

(3) Gliemeroth, G. 1948. Beeinflussung der Krümelung und der Krümeleigenschaften durch die Bodenfeuchtigkeit. Z. Acker- u. PflBau, 91, p. 29-60. 
(4) Heinonen, R. 1954. Multakerroksen kosteussuhteista Suomen maalajeissa. Summary: Moisture conditions in Finnish topsoils. Agrogeol. Julk., 62, p. 1-82.

(5) Meyer, L. \& v. Rennenkampff; U. 1936. Neuer Apparat und Methode zur automatischen Durchführung der Krümelanalyse nach Tjulin und Vorschläge zur Bestimmung des Krümelanteils, der Krümelgrössen und der Krümelfähigkeit des Bodens. Z. PflErnähr. Düng., 43 , p. $268-280$.

\author{
S E L O S T U S: \\ MAAN RAKENTEEN KAUSIVAIHTELUSTA \\ Reijo Heinonen ja Risto Pukkala
}

Maatalouskoelaitoksen maatutkimusosasto, Helsinki

Kolmesta koealasta otettiin kasvukauden 1949 aikana viisi kertaa näytteet, joista määritettiin näytteenottohetkellä esiintynyt kokonaishuokostila ja vesitila sekä ilmakuivassa maassa olevien vedenkestävien murujen määrä. Havaintosarja antoi aiheen seuraaviin päätelmiin.

Kokonaishuokostilan ja muruisuuden kausivaihtelu on niin laajaa, että eri aikoina otettujen näytteiden vertailukelpoisuus on hyvin rajoitettu.

Murujen määrä ja kokonaishuokostila riippuvat usein selvästi maan kosteuspitoisuudesta. Sen vuoksi on suositeltavaa, että erilaisen käsittelyn saaneet maat saatetaan vakiokosteuteen (kenttäkapasiteettiin) ennen näytteenottoa, jos tutkitaan niiden pysyväisluontoisia rakenneominaisuuksia ja halutaan välttää kausiluontoisten tekijöiden vaikutus.

\title{
Kun toteatte kirjastossanne \\ a u $\mathbf{k} \quad \mathbf{k}$ o $\mathbf{j} \mathbf{a}$
}

- kun haluatte hankkia uutta kirjallisuutta, soittakaa meille tai pistäytykää kurkistamassa, mitä Teitä kiinnostavia uutuuksia olemmə saaneet.

Nimenomaan ulkomaisen tieteellisen kirjallisuuden saanti on huomattavasti helpottunut — varmasti voimme toteuttaa Teidänkin toiveenne.

\section{Lähetämme aliisti \\ kirjallisuutta myös \\ nähtäväksi}

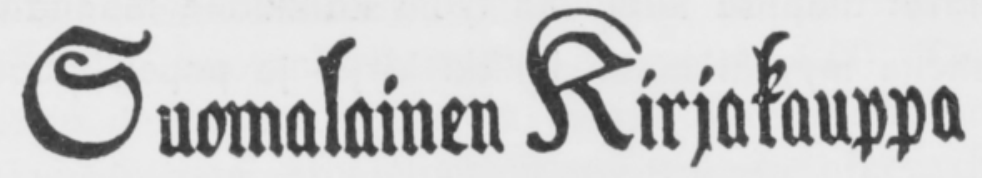

Helsinki - Vanha ylioppilastalo 